U. S. DEPARTMENT OF AGRICULTURE, BUREAU OF ANIMAL INDUSTRY.-CrRcULAR 174.

A. D. MELVin, Chief of BUREAU.

\title{
ERADICATING CATTLE TICKS IN CALIFORNIA.
}

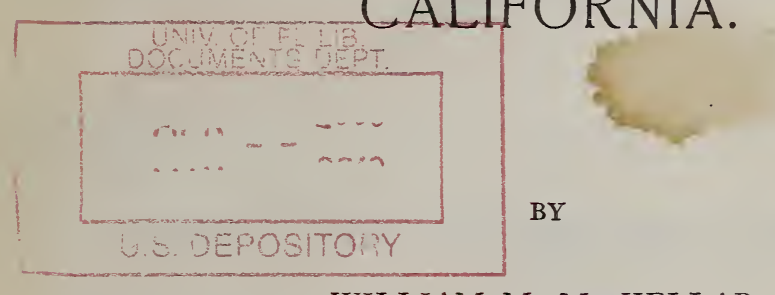

WILLIAM M. MACKELLAR,

Veterinary Inspector in Charge, AND

GEORGE H. HART, Assistant in Pathology and Bacteriology.

[Reprinted from the Twenty-sixth Annual Report of the Bureau of Animal Industry (1909).]

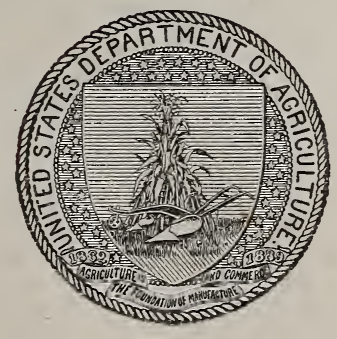

WASHINGTON :

GOVERNMENT PRINTING OFFICE.

1911. 


\section{ORGANIZATION OF THE BUREAU OF ANIMAL INDUSTRY.}

Chief: A. D. Melvin.

Assistant Chief: A. M. Farrington.

Chief Clerk: Charles C. Carroll.

Animal Husbandry Division: George M. Rommel, chief.

Biochemic Division: M. Dorset, chief.

Dairy Division: B. H. RAwL, chief.

Inspection Division: Rice P. Steddom, chief; Morris Wooden, R. A. RAmsay, and Albert E. Behnke, associate chiefs.

Pathological Division: JoHN R. MoHLER, chief.

Quarantine Division: Richard W. Hickman, chief.

Zoological Division: B. H. Ransom, chief.

Experiment Station: E. C. Schroeder, superintendent.

Editor: James M. Pickens. 


\section{CONTENTS.}

Losses from the ticks ............................................ 285

Early methods of combating gross infestation ........................ 286

Importance of State law ........................................ 287

Methods used in tick eradication in California....................... 288

International fence ......................................... 290

Dipping solution, its preparation and use ....................... 291

The dipping vats found most practicable........................... 293

The swim vat .......................................... 293

The cage vat. ........................................... 297

The wade tank ......................................... 299

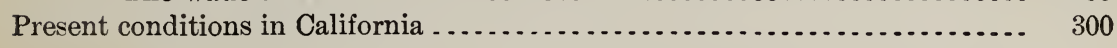

\section{L L US T RA TI 0 NS.}

Plate XV. Cage vat for dipping cattle............................ Page. 296

FIG. 7. Plans for wood or concrete dipping vat..................... 294

8. Plans for cage vat....................................... 297

9. Detail plans for cage vat................................ 298

10. Plans for small wade tank.............................. 299 



\title{
ERADICATING CATTLE TICKS IN CALIFORNIA.
}

\author{
By William M. MacKellaR, Veterinary Inspector in Charge, \\ AND
}

George H. Hart, Assistant in Pathology and Bacteriology.

\section{CONDITIONS PRIOR TO COIIMENCEMENT OF ERADICATION WORK.}

The history of the Texas-fever cattle tick in California covers scores of years. On account of its dating back long before the tick was known to be in any way connected with Texas fever, and at a time when differentiation of infectious diseases of bovine animals was little understood, resulting in anthrax, blackleg, and Texas fever being confused with each other and all classed under the lay term of "murrain," there is no way of ascertaining the exact origin of the tick in this State.

The common wood tick and castor-bean tick are very numerous in parts of California and are found on the cattle and horses in great numbers at certain seasons of the year. It is natural, therefore, that the invasion of the country by the deadly fever ticks attracted but little attention for a long time after their appearance and until they had secured a firm foothold.

Pioneer cattlemen of the State have different views as to the source from which the fever ticks were introduced. Thus it is held by some that they were brought across the Rocky Mountains on feeder cattle shipped into this country from Texas. As Mexico, however, has probably been infested since the early conquests of the Spanish, it is most plausible to consider that California received her first Texasferer ticks from cattle driven across the line from Lower California.

Until recent years the entire country was open range and movements of cattle were not controlled. The ticks, therefore, having been seeded in this country, and attracting no suspicion from cattlemen, had ample opportunity to spread and involve more of the southern section of the State. In every infested locality some one cattleman, who on account of having carried on the cattle business on a large scale involving the shipping in of cattle from other sections of this State and from other States, is accredited by his neighbors with the responsibility for bringing the ticks into that particular section. 
When the Texas-fever quarantine line was first placed across the United States in 1891 as a result of investigations by Dr. D. E. Salmon, the State of California was not included in the quarantined area. In 1894 outbreaks of Texas fever in Nevada, Kansas, and Missouri were reported as apparently caused by cattle originating in California. On account of these outbreaks of disease Mr. W. E. Hill, an inspector of the Bureau of Animal Industry, was directed to proceed to California and make an investigation. His investigation revealed that a large part of this State was permanently infested with Texas-fever ticks, and that great numbers of cattle had died of the disease in this State. The limits of the infested area not having been definitely determined, the entire State was subsequently placed below the federal quarantine line. Further investigation, however, having shown that the northern part of the State was free of ticks, the line was gradually moved south, so that in 1906 it crossed California at the northern limits of San Luis Obispo, Fresno, Madera, and San Bernardino counties, thus including the 13 southern counties of the State. All of the territory south of this line was not infested, on account of portions of the country being unfavorable to the propagation of the ticks. Although many of the counties in the quarantined territory had appointed live-stock inspectors, their duties involved attention to all infectious diseases, and movements of cattle within a county were without restriction. In this way all those sections favorable to the development of ticks became permanently ticky ranges, although in many instances they were separated by miles of mountainous desert, or extremely dry lands, where, on account of lack of feed, cattle could not remain the year round. Hence the ticks, even if well seeded on this land, failed to secure a permanent foothold.

Cattlemen learned, even before ticks were in any way connected with Texas fever, that certain ranges were dangerous for cattle, and thus in many instances after the loss of nonimmune cattle that had been placed on a ticky range this land was left free of cattle, and the starvation method of cleaning the land of ticks was thereby unconsciously accomplished. Thus areas within the State were constantly being cleaned, while others, on account of the early-day practice of driving a herd of cattle away from a range on which they were dying, became seeded. Such a condition of affairs existed when, in July, 1906, under the congressional appropriation for tick eradication, the Bureau of Animal Industry started the work of eradicating the ticks in California in cooperation with the State officials.

The work at first consisted in locating the ticky ranches and educating the owners of such land to the losses they were sustaining from the ticks and the benefits they would derive from eradicating them. This required careful and repeated inspections of all the cattle south of the quarantine line, and when completed showed San Luis 
Obispo, Santa Barbara, San Diego, Orange, Fresno, and Ventura counties to be heavily infested, and Tulare, Kern, Kings, Los Angeles, Riverside, San Bernardino, and Madera counties to be infested to a lesser degree. These counties comprised 69,755 square miles of territory, and contained 660,027 head of cattle, of which 153,476 were on tick-infested ranges.

\section{LOSSES FROII THE TICKS.}

The loss to the cattle industry south of the quarantine line in California from ticks has been enormous. This has been especially the case in this State on account of the topography of the country. In all the quarantined counties there is high mountainous land, or dry land with very hot summers, where ticks do not thrive. As a result there was constantly being raised, even in some very ticky counties, thousands of head of cattle yearly that reached maturity without ever becoming infested with ticks, and hence were not immune to Texas fever. From adverse feed conditions, as cold in the mountains or drought in the dry lands, cattle would from time to time be brought to more favorable feeding places, usually along the coast, which in the majority of cases were tick infested, and almost immediately they would commence to die in wholesale numbers. The mountain cattleman called the disease "coast fever," and from bitter experience learned to leave their cattle in the mountains or dry lands during adverse years, sustaining more or less heavy losses from starvation, rather than bring them to the coast on good feed only to stand much heavier losses from Texas fever.

Also, in the driving of cattle to favorable feeding places 50 to 100 miles distant, they would frequently be driven through some valley in the mountains that was tick infested; and although perhaps only remaining there overnight, in a short time afterwards, when miles away from the ticky valley, the cattle would start to die, and losses of from 50 to 100 head in this manner were not uncommon.

With the breaking up of many of the large ranges in California the raising of cattle to the fattening stage early became cheaper in the more remote States, as Arizona, Utah, Nevada, New Mexico, and western Texas, which were free of ticks. Thus many feeders, all nonimmunes, were annually shipped from these States to California to be fattened on the native grasses. Such cattle, when brought to ticky ranges in this State, died in such large numbers that the practice, while very profitable in the absence of ticks, had to be abandoned in many localities. Single cattlemen have been known to lose an entire train load of such cattle in a short time.

Among the immune cattle raised on ticky ranges, toward the end of the dry season, when feed was poor and ticks were so numerous as 
to "shingle" the cattle, a yearly loss ranging from 3 to 10 per cent was sustained, while on all of these places since eradicating the ticks this loss is entirely obviated.

On the grossly infested ranges it was sometimes necessary for stock owners to get off their beef cattle before they were in prime condition, rather than keep them until later in the season, when, from the heavy infestation, they would fall off instead of gain.

In some of the quarantined counties the trading in cattle became so hazardous as to be almost abandoned, owners being afraid to buy or move stock on account of great losses sustained by neighbors on all sides from such a procedure.

In the counties where dairying is the main industry, the shrinkage in milk production among the grossly infested herds during the summer and fall, while hard to estimate accurately, would increase the economic loss from the ticks to a considerable extent.

A great saving to the railroads in car disinfection has also been accomplished, since a large part of the original area quarantined in the State has been released.

\section{EARLY METHODS OF COMBATING GROSS INFESTATION.}

Prior to the commencement of the eradication work many ranges containing fine feed were so heavily infested with ticks that raising and fattening cattle on them was a difficult problem. The cattlemen in many instances did not believe in the so-called tick theory of Texas fever, but they considered that from their enormous numbers the ticks were an injury on account of the parasitic existence they maintained on the cattle, which was constantly demonstrated by the large percentage of deaths among immunes during times when feed was short. It therefore was a general practice for ranchers in the summer and fall to resort to various methods to destroy the ticks. The time and labor expended in this procedure were great and their value slight and of a very temporary duration. On some of the ranches the range cattle were corraled, roped, and treated one at a time by hand, either by currying off the ticks or applying various solutions, as crude oil, coal-tar preparations, kerosene oil, or carbolic acid, which in all cases killed only a portion of the ticks and often injured the hides of the cattle more or less seriously. On the very large ranches, containing many thousand head, treating all the cattle individually was impossible, and after corraling a bunch only those most hearily infested were picked out for treatment. Even this absolutely ineffective method required weeks of labor.

In other cases, wild cattle would be crowded into chutes and sprayed through openings in the sides, by which method it was impossible to wet with the solution the parts of the animals where the ticks were most numerous. In the dairy herds spraying and swab- 
bing were resorted to at irregular intervals. On some ranches chickens were accredited with assisting in retarding tick development by entering the corral and feeding on the adult ticks picked from the bodies of cattle in the recumbent position.

On one large grant of land comprising 17,000 acres along the ocean front, it was the custom to drive the cattle into the ocean and hold them against the bluffs where the waves could beat against them. This mechanical action of the waves had the effect of dislodging the large ticks, and they dropped into the ocean, where they perished. The measure, although very crude, was easy of accomplishment and resulted in some benefit.

Owners of some of the larger ranches in order to combat ticks built dipping vats. These they filled with water, on the surface of which a thin float of oil or distillate was placed, in some cases not over onequarter to one-half inch thick. Cattle were rounded up and run through such vats when the ticks became too numerous, but the permanent good so derived was slight.

\section{IMPORTANCE OF STATE LAW.}

On account of actual tick-eradication work being in no way connected with the interstate movement of cattle, federal laws are inoperative with regard to cattle kept within a State. It is therefore essential that Bureau employees engaged in this work be deputized under the state law so that they may carry out all the various provisions of a practicable tick-eradication law.

While in all cases it expedites matters and is more pleasant for the cattle owners and inspectors to work harmoniously in the eradication of the ticks, a stringent state law is absolutely necessary, as there are always a few stockmen who refuse to see the advantage to themselves and the community in eradicating this pest. In order to compel such indifferent owners to disinfect their cattle properly a state law should be enacted giving the state authorities the power to enforce disinfection and making it a misdemeanor for the owners not to comply with such requirements.

Through the efforts of the state veterinarian, Dr. Charles Keane, the State of California, in March, 1907, enacted a law which makes it a misdemeanor to move or expose tick-infested cattle in such a manner as to infest other cattle or live stock not so infested. This law also provides for the disinfection of cattle as directed by the state veterinarian or his deputy, and provides that in case of failure on the part of the owner so to disinfect, the state veterinarian has the power to disinfect the cattle, the cost of the treatment becoming a lien on them. This law, while having weak points that should be corrected to cover certain special conditions, has been of inestimable value in the work of tick eradication in California.

$82882^{\circ}-11-2$ 


\section{METHODS USED IN TICK ERADICATION IN CALIFORNIA.}

On account of the present high valuation of range lands, the absence of feed-lot methods of fattening, and the stocking of all sections to the full capacity with live stock, the practice of "resting" pastures to clean them is impracticable in the great majority of cases in California. This method, however, is one which gives rapid results with little work, and when the number of cattle on the ranch will permit of its use it is an easy method of accomplishing the desired results. In this State it is recommended that all cattle, horses, mules, and asses be excluded from the resting pasture for eight months, resting preferably to begin between May 1 and October 1 , when all tick eggs that may be on the pasture are sure to hatch before the approach of cold weather.

From the lack of rains during the summer season and the excessive valuation of irrigable lands, where forage crops could be raised for use in the pasture-rotation method, this resource for ridding a ranch of ticks has also been impracticable.

Tick eradication therefore resolved itself into a problem of cleaning the ranges while the cattle were constantly grazing upon them. Under such conditions the first essential to success is the installation of a dipping vat. It has been our experience under usual conditions in this State that time used in spraying, smearing, currying, hand picking, or other means without the dipping vat is mostly wasted. These latter methods may be entirely successful with single eows, but where there are a dozen head or more such measures require two or three years, and before success is attained the owner is discouraged and disgusted. When the herd comprises over 50 head, it has, in our experience, proved to be practically impossible to clean without the vat.

After the vat is installed the owner must be thoroughly informed at the beginning what will be required of him to clean his ranch, and impressed with the possibility of freeing his land and cattle in one season. His cooperation is necessary, but even when this is given constant supervision by the inspector is necessary to prevent laxity and overlooking of details which are absolutely essential to success. Thus on a ranch containing infested cattle a single improper mixing of the dipping solution or the failure to get a few head to the vat at a dipping in the middle of the dipping season may destroy the opportunity of cleaning the ranch with that year's work.

Although the eradication work in one community has been very successful and cleaning of the ranches has proceeded without interruption, this fact when used as an argument for thorough and regular dipping in another section often has little effect on obstinate owners of tick-infested land. 
During the process of cleaning, which entails time, labor, and expense on the part of the cattleman, he is almost sure to become discouraged; and when, after having dipped his cattle three or four times, they continue to come up to the vat for the fourth or fifth dipping showing ticks, he commences to feel that his efforts are going to be in vain. At this stage of eradication even the most enlightened cattlemen who appreciate the benefit of exterminating the ticks are liable to become so discouraged as to be disagreeable when approached by the inspector in regard to further dipping. At this time tact on the part of the inspector is very essential. Many cattlemen who have made irritating and even insulting remarks to the inspectors during the time of actual eradication work have, after this was completed and when they realized that their ranches were free of the pest, become strong in their praise of the work and the economic good it has done them personally and will do the country at large.

During the dipping season, when the ranches are heavily infested, horses, mules, and burros running on the range require attention, and should be dipped or otherwise freed from ticks. When there is slight infestation of the range, solipeds require little attention.

The dippings can be separated by intervals of thirty days under ordinary circumstances when the infestation is slight or moderate. When the range is very heavily infested it is better to dip at shorter intervals, twenty-one to twenty-eight days, for several months or until the ticks begin to show a reduction in numbers, when the intervals between dippings may be extended to thirty days. When infested cattle are to be moved to a tick-free pasture, two dippings must be required, separated by an interval of five to fourteen days.

The dipping season in California begins about April 1 and must continue at thirty-day intervals until eight or nine dippings have been made in order to clean the range in one season. During these eight or nine months it is necessary for the inspector to be present at each dipping and supervise the mixing of the dipping fluid in person. He should know the exact number of cattle on each infested ranch, and where possible should count the cattle at every dipping as they are let out of the draining pen, to be sure that the owner has made a clean roundup.

On the slight or moderately infested ranges after several dippings the cattle will often come to the vat apparently free from ticks, and the owner will therefore object to further dipping. In such cases the absolute necessity for continuing the disinfection throughout the season must be impressed upon him.

In many localities in California where infestation existed the country was divided up into small ranches, 40 to 120 acres. Such ranches were separated by a single line of barbed-wire fence, and all con- 
tained cattle. Upon ranch-to-ranch inspection of such localities, in inany instances ranches would be found tick free when surrounding them on one or more sides ticky cattle were known to be grazing. Such ranches were kept under close observation throughout the eradication work, and remained clean. It is thus seen that it is quite practicable for a single line of good fence to prerent the spread of the Texas-fever tick. As a result of our observations in this matter it would seem to be unnecessary to augment the cost of eradication by insisting on double division fences.

In dividing large ranges by cross fences, for the purpose of tick eradication, as far as possible the single fence should be made to traverse rough, inaccessible land where feed is short and where cattle will consequently have little tendency to stray directly up to the fence.

INTERNATIONAL FENCE.

Tick eradication along the California-Mexico line is complicated by the fact that parts of Lower California, especially the coast section, is heavily infested with ticks. It being largely a range country, bady tick-infested live stock from that country were constantly drifting and straying across the international line and undoing any efforts of the American ranchers in this section to eradicate the ticks from their land. Consequently it became apparent that if the ticks were to be eradicated in this locality it would be necessary to control this movement of tick-infested Mexican live stock. Without such control ranchers in this section consider it a hardship to have to attempt to free their land of ticks, only to have it reinfested by stray Mexican animals, and, consequently, their cooperation in the work can not be secured.

The only feasible method of securing this control of live stock is the construction of a stock-proof fence on or near the international line. The necessity for such a fence has long been recognized by the ranchers in this section, and some, to protect their feed and to assist in freeing their cattle of ticks, have constructed fences of a more or less temporary character at irregular intervals along the line; but in most cases it has been necessary to abandon the eradication work in this section pending the construction of a proper fence. It was soon ascertained that such a fence could not be constructed without gorernment assistance. The Bureau of Animal Industry has therefore undertaken to construct a first-class stock-proof fence along this line, wherever necessary, to prevent the entrance of infested Mexican live stock. With this fence installed, eradication in this section will soon be accomplished and future reinfestation prevented. Such a fence will also assist the customs officials in preventing illegal traffic between the two countries. 


\section{DIPPING SOLUTION, ITS PREPARATION AND USE.}

At the commencement of the work by the Bureau in the summer and fall of 1906 the oil-float dip was used. This was prepared by filling the vat with water, after which 1 to 2 inches of oil was floated on the surface. The oil used was a California product, and while samples from several wells seemed to be nearly identical with Beaumont oil, injurious results to the cattle of a more or less serious nature followed in most instances. This probably was largely due to the extreme heat of California summers and the absence of shade on the ranges. While ticks on the cattle were killed by this measure when properly carried out, reinfestation soon occurred, and redippings at sufficiently short intervals to prevent reseeding of the ranges was impossible. The oil float having been found injurious, attempts to use crude petroleum alone after the methods followed in the Eastern States was abandoned. On account of the insurmountable opposition on the part of the cattlemen to the use of oil, it soon became apparent that tick eradication in this State would be impossible unless some other less injurious disinfecting solution could be obtained.

The following year the arsenical solution was tried in several vats with such satisfactory results to stock owners and inspectors that its general use was at once inaugurated and has been continued uninterruptedly to the present time. In this solution, properly prepared, cattle can be dipped nine or ten times in one season and remain in as good if not better condition than cattle on adjoining pastures with identical feed that have not been dipped.

The solution used in California is made after the following formula:

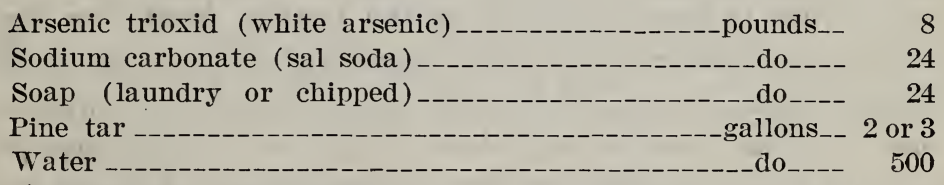

For mixing the preparation it is necessary to have at the vat one or two caldrons or tanks of a capacity of not less than 50 gallons in which to dissolve the ingredients. As the water in the caldron warms the sodium carbonate is added and dissolved by stirring, after which the arsenic is added and the fluid brought to the boiling point and stirred until all is in solution. To expedite matters, the soap may be cut up and heated at the same time in the second caldron or dissolved in the arsenic and soda solution when only one tank is available. These three ingredients being dissolved, the fire is then drawn, and the tar is slowly added, with constant stirring to make a homogeneous solution. This concentrated solution is then added to the 
water in the vat to make the proper proportion, as given in the preceding formula. When filling a large vat of a capacity of 3,000 or 4,000 gallons, several boilings have to be made, unless the cooking tank is quite large.

The soap, in our opinion, is a valuable ingredient of the preparation. It gives body to the dip and tends to make it adhere to the hides. This is important, as the solution acts as a gradual poison to the ticks, requiring several days to kill when the parasites are nearing maturity. It also cleans the hair of the cattle, thus improving their appearance after dipping, and may have a slight effect in preventing reinfestation for a longer time than when they are dipped in an arsenical solution without the soap. It also assists in emulsifying the tar and rendering the solution homogeneous. These advantages far outweigh the slight extra cost of its use. The addition of the larger quantity ( 3 gallons, instead of 1 gallon, as usually recommended) of pine tar is recommended, as it is also valuable in giving body to the mixture and increases its action as a parasiticide. In addition, it has been found that the greater the proportion of tar the longer cattle are free from annoyance by flies following dipping.

While the solution made after the above formula is most satisfactory for dairy and fine-bred cattle, more arsenic may be added, up to 9 or 10 pounds to the 500 gallons, in the disinfection of range cattle.

When once filled, the vat is ready for use at all times, unless rains should dilute its contents, when ingredients have to be added in the proper proportions for the amount of rain water which has fallen or drained into the tank. In exposed tanks the amount of evaporation is considerable during the hot summer months, reducing the fluid in the vats as much as 3 inches between dippings. In adding ingredients to keep the fluid at the proper depth for dipping, this evaporation does not have to be accounted for, and the medicinal ingredients should be added in full proportion for all water used. The same solution remains active as a tickicide indefinitely, but the number of times it should be used for redippings depends entirely on the number of cattle dipped each month. Dirt carried in on the hoofs; hair which comes off the animals in considerable quantities during the shedding season, and urine and feces evacuated by the cattle in the vat and draining pen tend to befoul the solution. When therefore the number of cattle dipped monthly reaches into the hundreds of head it is our practice to clean out the vat after each three dippings.

Following dipping in arsenical solution care must be used in driving cattle to prevent overheating, as injurious and even fatal results have followed forced driving, especially during hot weather.

While this solution is very poisonous, it has been used very extensively in this State with no bad results, and with ordinary precautions 
its poisonous nature is not a good reason against its use. It is our practice to place on each vat in which the solution is used a notice reading as follows:

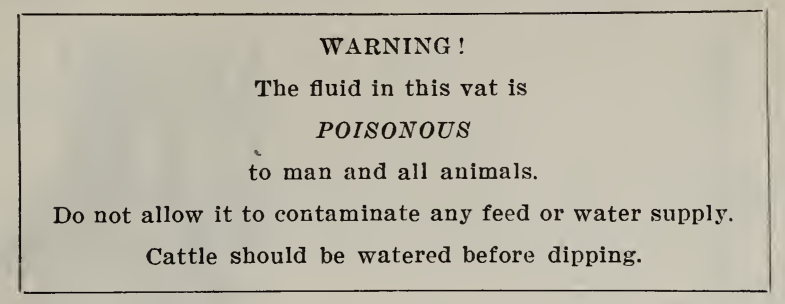

THE DIPPING VATS FOUND MIOST PRACTICABLE.

Dipping being the most practicable method of disinfecting cattle for eradicating ticks, it is necessary for those engaged in eradication work to become familiar with the various kinds of vats, in order that the most suitable form may be recommended under the various conditions met, depending on the kind and number of cattle to be treated and the financial condition of the owner.

In communities where several small tick-infested ranches are located within a short distance of each other cooperative vats have been established. The several owners of the infested places would club together, select the most convenient location to build the vat, and subscribe the necessary money for its installation. One rancher is appointed treasurer, and it is his duty to collect all money for dipping, buy the dipping materials, and act as manager of the plant. A charge is made for dipping, usually not over 5 cents a head, and if at the end of the dipping season there is a surplus this is divided among the subscribers. In this way the several ranchers have the advantage of a dipping vat without each being put to the cost of installing one. A dipping day is set once each month, and all infested herds are dipped at this time, the owners assisting each other in the operation.

In other cases one rancher will install the vat and allow his neighbors to dip their cattle in it, charging a nominal fee for the service.

In California three styles of vats are used, namely, the swim vat, the cage vat, and the wade vat.

\section{THE SWIM VAT.}

The swim vat is by far the most practical for range stock and where large numbers of cattle are to be dipped. It has the advantage of speed and requires little labor in the operation of dipping. The longer such a vat can be constructed, up to 50 or 60 feet at the dip line, the better, as it has been found that the action of the arsenical solution is more potent if the cattle are submerged for at least twenty 
seconds, and such a length of time is recommended when mature ticks are present on the cattle. However, in this State successful results have followed the use of much shorter tanks. Such vats may be
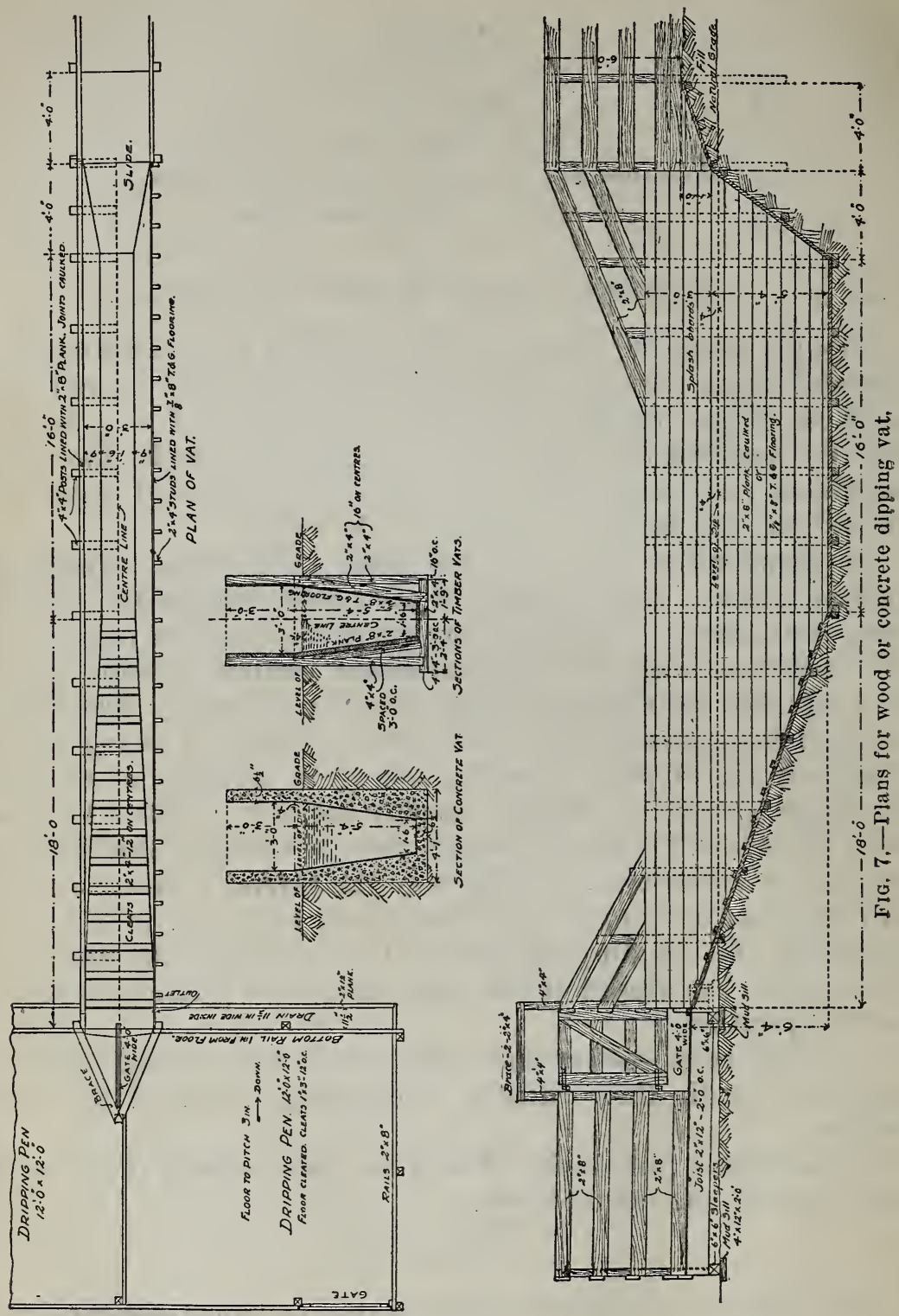

constructed of lumber or cement. The latter is preferable, as it has not the disadvantage of leaking, which is common in wooden vats, and is more durable. A swim vat built after the plans shown in 
figure 7 will prove very satisfactory. This figure, as well as the following specifications and list of materials, is taken from Farmers' Bulletin 378, by H. W. Graybill. A vat constructed according to these plans will hold 2,088 gallons when filled to a depth of 5 feet. In our experience in the use of such vats in California it has been found advantageous to construct the vat with a somewhat steeper slope at the entrance end than is indicated in the plans. With this modification the cattle are plunged more quickly into the vat, and time can be saved in dipping a large number of animals.

Excavation.-Excavate for the vat, as shown by the drawings (fig. 7), to the proper depth. Level the bottom of the pit for the sills. After the vat is completed fill in around it, using the surplus earth to bring the grade at the sides of the vat a little above the natural grade and slope the surface away from the vat. Dig the holes required for all posts, etc.

Carpenter work.-The drawings show the vat constructed according to two methods. One method is to make the sides of 4 by 4 inch posts spaced about 3 feet apart and lined with 2 by 8 inch dressed, sized, and bevel-edged plank, using 20-penny spikes to fasten them to the posts and braces. All the joints are to be calked with oakum well driven in with a calking iron and pitched. The floor of the vat and the inclines are to be made of 2-inch plank with joints calked, the exit incline to have 2 by 4 inch cleats spiked to the plank flooring. The slide should have an angle of about $25^{\circ}$ and should be covered with No. 16 galvanized iron.

The other method is to build the sides of the vat of 2 by 4 inch posts and 2 by 4 inch braces spaced about 16 inches on centers. The 2 by 4 inch posts and braces are to be lined with $\frac{7}{8}$ by 8 inch tongued-and-grooved flooring, blind nailed at every bearing with 10-penny nails. All the joints are to be laid in white lead paste and the boards firmly driven up.

Lumber.-The lumber used in the construction of the vat must be thoroughly dried and seasoned stock, free from large and loose knots, straight grained, and free from sap.

Gutters.-The gutters for the dripping pens should be made of sound stock, the bottom plank housed into the sides and ends, and the ends housed into the sides. All the joints are to be laid in white lead paste and thoroughly nailed. Gutters are to have 3-inch fall in 11 feet.

Concrete vat.-The concrete vat should be made of concrete composed of 1 part by measure of good Portland cement, 3 parts of clean sharp sand, and 5 parts of broken rock, the broken rock to be not larger than will pass in any direction through a 2-inch ring. The rock should be washed free of dust. Concrete should be mixed wet and well tamped into place.

Bill of materials.-Lumber for vat when constructed of 2-inch material and 4 by 4 inch posts:

Sills____ 8 pieces 4 by 4 inches by 10 feet long.

1 piece 4 by 4 inches by 16 feet long. 1 piece 4 by 4 inches by 14 feet long.

Posts 6 pieces 4 by 4 inches by 12 feet long.

5 pieces 4 by 4 inches by 10 feet long.

1 piece 4 by 4 inches by 16 feet long.

Braces 6 pieces 4 by 4 inches by 12 feet long.

1 piece 4 by 4 inches by 10 feet long.

1 piece 4 by 4 inches by 6 feet long. 


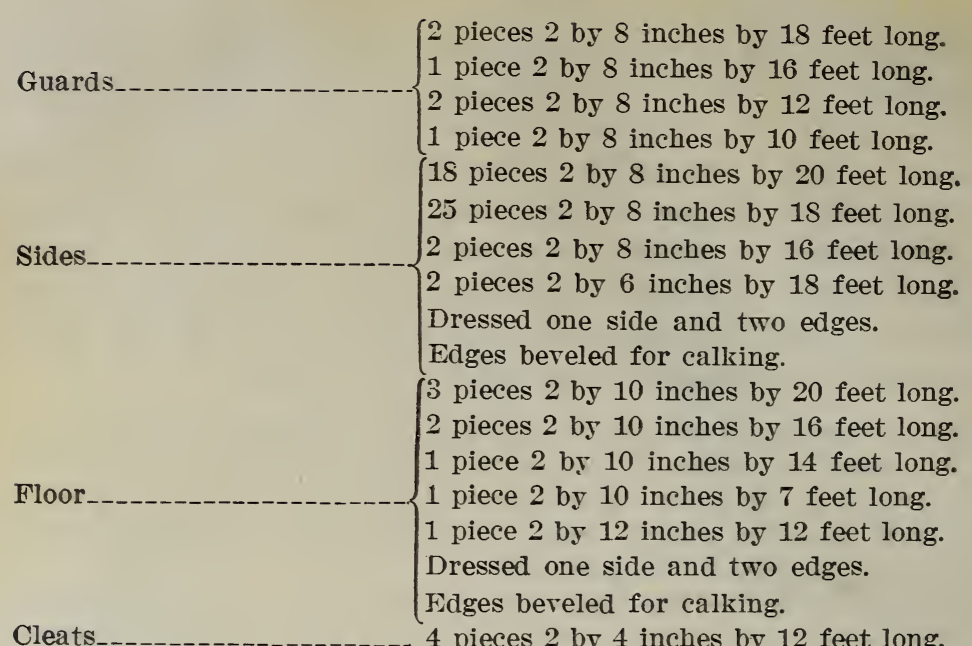

Lumber for vat when constructed of flooring and 2 by 4 inch posts :

Sills

Posts

Braces

Guards

Materials the same as specified abore.

Sides 550 feet b. m. $\frac{7}{8}$ by 8 inches tongue-and-groove flooring.

Floor Materials the same as specified abore.

Cleats Materials the same as specified abore.

Lumber for draining pens :

Mud sills

Sleepers

Joists

Floor

Cleats

Gutters___ $\left\{\begin{array}{l}\text { Sides : } 4 \text { pieces } 2 \text { by } 12 \text { inches by } 11 \text { feet long } \\ \text { (dressed). } \\ \text { Bottom and ends : } 2 \text { pieces } 2 \text { by } 12 \text { inches by } 12 \\ \text { feet (dressed). } \\ \text { Bottom housed into sides and ends. Ends housed } \\ \text { into sides. All joints calked and white leaded } \\ \text { or pitched. }\end{array}\right.$

10 pieces 4 by 12 inches by 2 feet long (cedar or cypress).

4 pieces 6 by 6 inches by 12 feet long.

13 pieces 2 by 12 inches by 12 feet long.

360 feet b. m. tongue-and-groove flooring $\frac{7}{8}$ by 8 inches-12-foot pieces.

265 linear feet 1 by 3 inches.

11 pieces 4 by 4 inches by 7 feet long.

2 pieces 4 by 4 inches by 8 feet long.

2 pieces 4 by 4 inches by 9 feet long.

2 pieces 2 by 8 inches by 18 feet long.

Rails 5 pieces 2 by $S$ inches by 16 feet long.

18 pieces 2 by 8 inches by 12 feet long. 


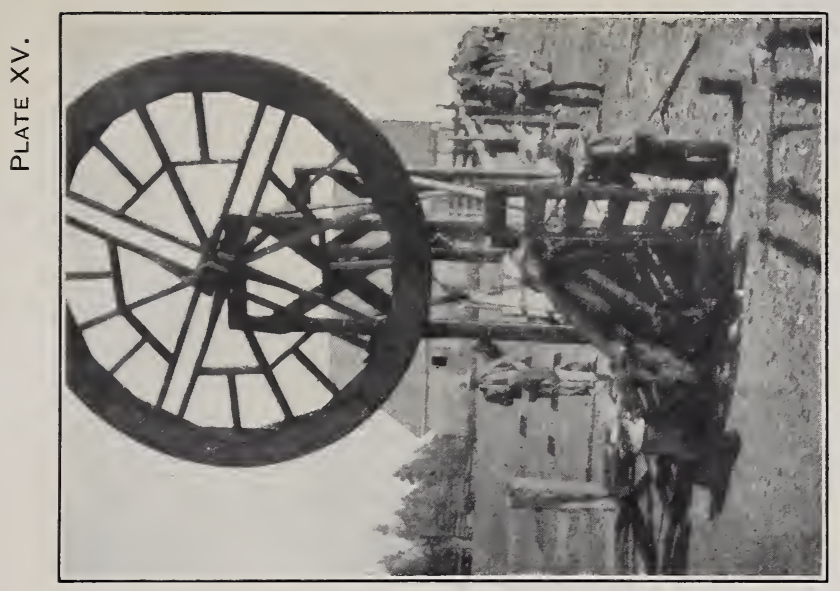

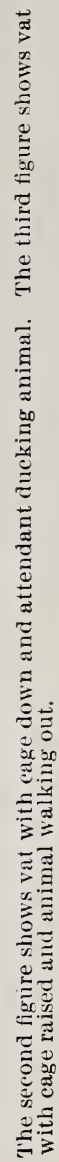
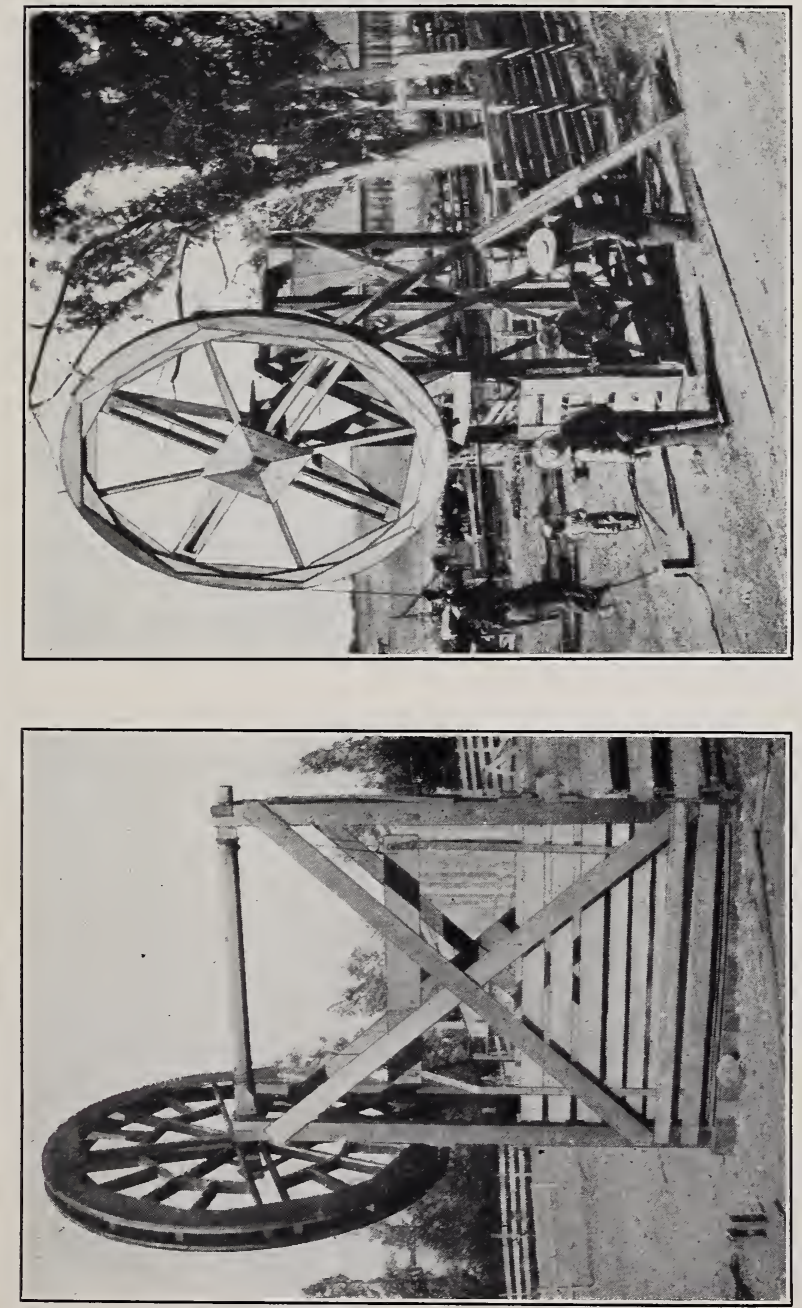



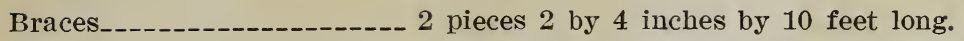

Gates

Hardware for vat and draining pens:

4 pair 12-inch heavy $T$ hinges and screws.

4 wrought-iron hooks and staples.

I pair wrought-iron hook hinges, 12-inch wood screw hooks, and screws.

50 pounds 20-penny wire nails.

15 pounds 10-penny wire nails.

12 square feet No. 16 galvanized iron.

When vat is constructed of flooring and 2 by 4 posts, the following additional hardware will be required:

19 pounds 20-penny wire nails.

12 pounds 10 -penny wire nails.

Material for concrete vat:

Concrete, 1 part Portland cement, 3 parts sand, 5 parts broken rock or gravel.

19 cubic yards broken rock or gravel.

18 cubic yards sand.

30 barrels Portland cement.

THE CAGE VAT.

The cage vat, when properly constructed, is very practical and is recommended for the disinfection of smaller herds and gentle cattle, especially dairy cows. It has the advantages of being economical in the amount of dipping solution necessary to charge the vat; animals may be held in the solution as long as desired, and the operation of dipping is almost entirely without rough handling or worry to the cattle. This last is an important factor in the disinfection of milch cows without causing shrinkage in the milk flow. Dairy herds should be dipped in the morning immediately after milking.

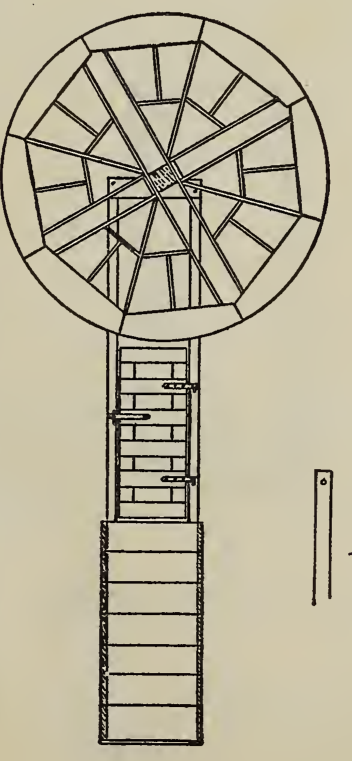

FRONT VIEW

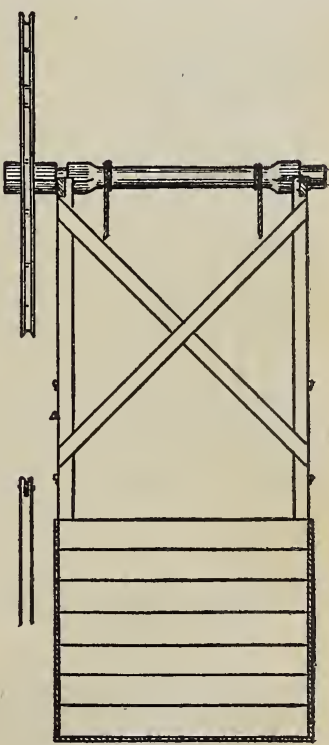

SIDE VIEW

FIG. 8.-Plans for cage vat. They can then be turned out to pasture with very little time lost from feed. Plate XV and figures 8 and 9 show this form of vat as it has 
given most satisfactory results in California. The following specifications and bill of materials are given for its construction:

Tank.

The tank should be made 7 feet deep, 3 feet wide, and 8 feet long, inside measurements.

Four corner posts, 4 by 6 inches by 18 feet, must be planed on outer sides to join planks for sides and ends.

Sides, 7 planks 2 by 12 inches by 16 feet cut to 8 feet long.

Ends, 3 planks 2 by 12 inches by 12 feet cut to 3 feet long.

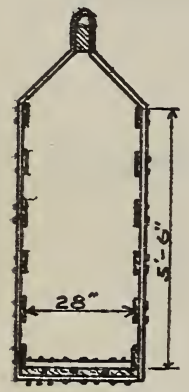

$a$

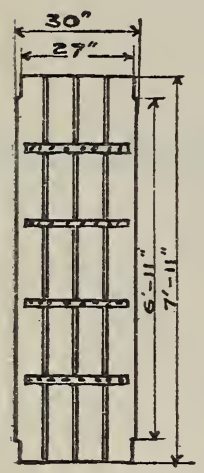

$c$

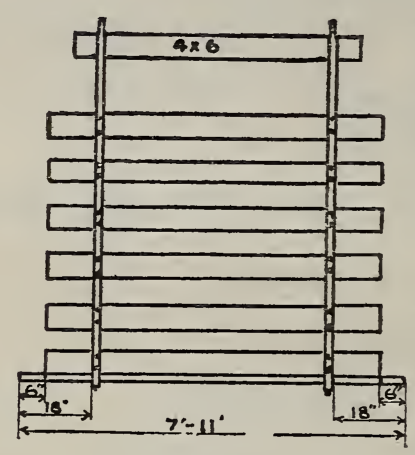

$b$
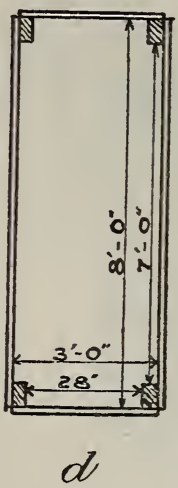

Ends, 1 plank 2 by 12 inches by 16 feet cut two pieces 3 feet long; left over, 2 by 12 inches by 10 feet.

Bottom, use left-orer 2 by 12 inches by 10 feet cut to 3 feet 4 inches long.

Bottom, 2 planks 2 by 12 inches by 12 feet cut to 3 feet 4 inches long.

Braces, ends, and sides, five 1 by 6 inches by 12 feet.

Gates, two 1 by 6 inches by 14 feet.

Gates, two 1 by 6 inches by 12 feet.

Gates, four hinges and two hooks.

Cage.

Floor, two 2 by 6 inches by 16 feet cut to 7 feet 11 inches long.

Floor cleats, one 2 by 3 inches by 12 feet cut 28 inches long.

Sides, six 1 by 6 inches by 14 feet cut to 6 feet 11 inches long.

Top piece, one 4 by 6 inches by 6 feet.

Make hangers of $\frac{1}{2}$ by 2 -

FIG. 9.-Detail plans for cage vat; $a$, Cross section of cage; $b$, side view of cage; $c$, floor of cage; $d$, cross section of tank. inch iron.

Wheel.

Shaft, one 8 by 8 inches

by 10 feet, turned to set in bed pieces.

Three-eighths-inch cable or chain attached to shaft to raise cage.

Bed pieces, make two 3 by 8 inches by 3 feet.

Spokes, twelre $1 \frac{1}{2}$ by 3 inches by 12 feet.

Flanges, four 1 by 12 inches by 16 feet.

Have flanges extend 3 inches over ends of spokes and run rope over free ends of spokes.

Use $\frac{3}{4}$-inch rope 140 feet long, have pulley in a block sunk in ground, and lift cage with saddle horse or horse and traces. 
Lumber and milling companies furnish these materials, sized and cut in proper manner, to the ranchers for from $\$ 55$ to $\$ 65$. The builder then has in addition the labor of excavating the pit and putting the tank together. Draining pens with such vats are not essential and are rarely used, as the animal drains while the cage is being raised.

This vat is installed near the corrals and requires only a short chute leading from the corral to the cage. In operating such a vat the animal is driven through the chute into the cage and the end gate closed. The hoist rope is released and the weight of the animal carries the cage down into the fluid. If the animal is not completely submerged, its head is forced under by the foot of an assistant wearing rubber boots. After remaining in the solution the proper length of time (twenty to thirty seconds) the cage is raised by attaching

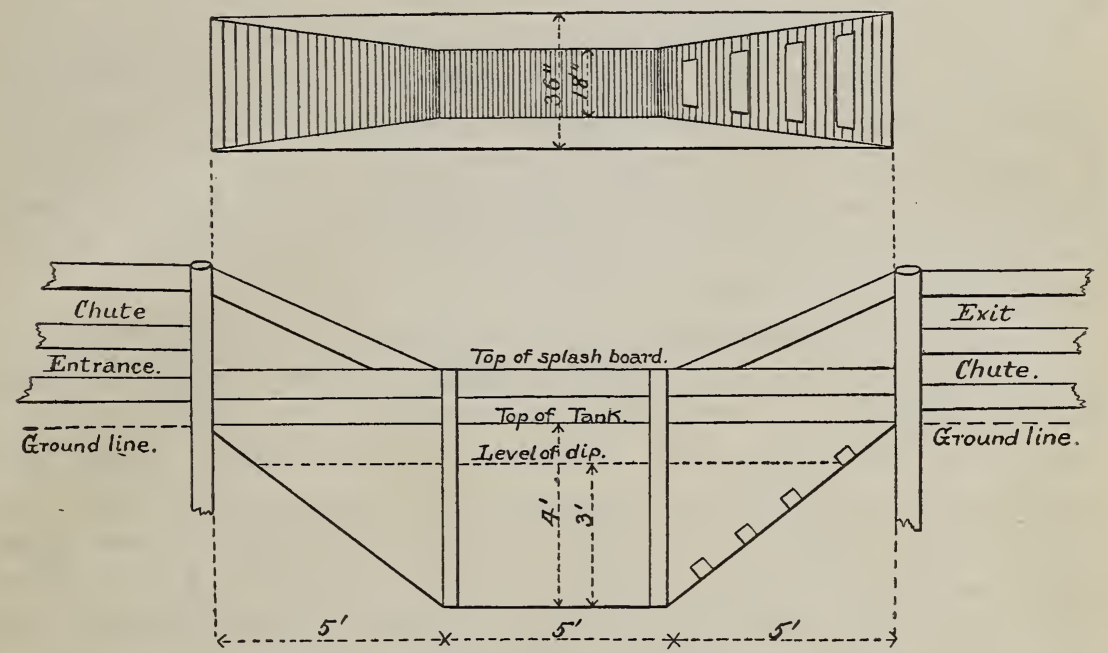

FIG. 10.-Plans for small "wade tank." Vertical section.

the end of the hoist rope to the saddle horn or the swingletree of a horse in harness. During the raising of the cage the animal drains, and after a short interval the opposite end gate is opened and the animal passes out. With this vat from 30 to 50 animals can be dipped per hour.

\section{THE WADE TANK.}

The wade tank is recommended only in the disinfection of very small herds. It can be constructed with an outlay of less than $\$ 10$ for materials, thus being cheaper than a good spray pump. Figure 10 shows plans of such a vat, which can be made of either lumber or cement.

In the use of this tank the animal is led in by a rope or halter and cross-tied or held. The solution in the vat, being 36 inches deep, 
thoroughly saturates the lower parts of the body and sides, which are always most heavily infested and most difficult to reach with a spray pump or swab. The upper parts of the body are then thoroughly wet by pouring the dipping solution from a pail over the head and back. The animal is then led out at the opposite end of the vat and allowed to drain on the incline or in the chute. With this method less fluid is used than in spraying or swabbing, the operation is easier to perform, and it is efficacious.

\section{PRESENT CONDITIONS IN CALIFORNIA. ${ }^{a}$}

As a result of four years' work by the Bureau and state officials, California has only 9,315 square miles, instead of 69,755 square miles, of territory in quarantine for Texas-ferer ticks. Of this area remaining in quarantine a large percentage is at present tick free and should soon be in a condition to be released.

Of the original 153,476 cattle infested there remain under local quarantine 41,906. This number includes all herds on which the slightest infestation has been found in 1910, and many of these will no doubt be free with the close of this season's work. Half of this number are on one large ranch where eradication work has been slow on account of its size, the roughness of the range, and lack of cooperation from the owner.

Prior to the inauguration of tick eradication in California condemnations for Texas fever were numerous in the abattoirs having federal inspection. During the past two years not a single condemnation for this disease has occurred in Los Angeles, where the majority of the cattle from the quarantined area are slaughtered. In the past year deaths from Texas fever on the ranges, where some years back losses annually reached into the thousands of head, have been so few as to be hardly worthy of notice. Our experience has proved that tick eradication is not only possible, but with stringent laws and proper methods is very practicable. When attained it returns to the individual owner and the cattle industry at large many times more than the cost of its accomplishment.

\footnotetext{
${ }^{a}$ Data brought down to summer of 1910.
}

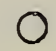




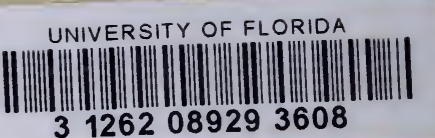

